\title{
Community Theater as social support for youth: agents in the promotion of health
}

Denise Diba ${ }^{1}$

Ana Flavia d'Oliveira ${ }^{1}$
${ }^{1}$ Departamento de Medicina Preventiva, Faculdade de Medicina, Universidade de São Paulo. Av. Dr. Arnaldo 455, Cerqueira César. 01246903 São Paulo SP Brasil. denise.diba@ig.com.br

\begin{abstract}
There has been much discussion on promotion of the health of young people in vulnerable situations; but little work has been done analyzing its actual operation - and this is especially true in relation to programs and projects that are outside the health services. This article aims to analyze the relationship of an experience in Community Theater with the promotion of health. It is a qualitative, ethnographic study made at the Pombas Urbanas Institute, in the Cidade Tiradentes district of the municipality of São Paulo, and is coordinated by a theater group with a history that is relevant to the objective of the study. Participatory observation was carried out for one year, with semi-structured interviews with young people, and with actors of the Pombas Urbanas group, and analysis of documents. The theoretical framework that was used is made up of concepts from the fields of collective health, Community Theater, and liberation pedagogy. The results are presented in two interlinked sub-categories which have arisen from the empiric material and from the references adopted: (i) 'True friends', and (ii) 'Dialog. The analysis clearly shows the importance of this type of theatrical joint experience for the promotion of health by transforming the quality of relationships between people. Concepts of health, culture and education were used in analysis of the results.
\end{abstract}

Key words Youth, Art, Promotion of health, Social support, Aspects of culture 


\section{Introduction}

Youth can be an intense period of challenges, discoveries and decisions ${ }^{1-8}$. While on the one hand the circumstances we live in and the sometime transient or intense nature of our relationships can make people more vulnerable ${ }^{1-8}$ to becoming ill or to social conditions that can result in illness, on the other hand having relationships with people whom one can count on at moments of difficulty can be seen to be a significant element for reducing this vulnerability.

This article comes from the master's degree dissertation 'From a Drug Point to a Culture Point: Theater as Promotion of Health for Youth - the Pombas Urbanas Group in the Cidade Tiradentes district of São Paulo'. That work seeks to understand how coexistence, working and acting together in a 'community theater ${ }^{\prime} 10,11$ modality contributes to the empowerment of, and reduces the vulnerability of, young people, so that it can be considered as a factor that promotes health.

In this article we focus especially on the dimension and concept of social support, and its important function in the interaction of community theater and promotion of health. Several authors ${ }^{12-14}$ put forward that social support is one of the fundamental elements for the promotion of health. This is also dealt with in the Health Ministry's document on the National Health Promotion Policy (Política Nacional de Promoção da Saúde, or PNPS) ${ }^{15}$, and in the Letters from conferences on promotion of health ${ }^{16}$.

Before going further, we will briefly summarize what we understand to be the meaning of three terms: 'promotion of health', 'community theater', and 'social support'.

Promotion of health: The concept of promotion of health arose in the 1940s, and currently includes points of view from the most conservative to the most progressive. It is considered that the various conceptualizations can be divided into two major groups: one that almost exclusively highlights individuals' own responsibility for their health; and another that calls attention to the importance of multi-sector public policies that aim to improve the quality of life of populations ${ }^{17-19}$, so as to give the exercise of that responsibility the power to be effective.

Brazil adopted a National Health Promotion Policy (PNPS) in $2006^{15}$. That policy contains this proposal: The scope of health interventions should be widened, to take as their objective both the problems and needs of health and also their determining and conditioning factors, so that the organization of healthcare involves both the actions and services that operate on the effects of becoming ill, and also those that work beyond the walls of the health units and the health system, and affect conditions of life.

What is of interest to us here is to examine the promotion of health, in the context of artistic production, beyond the health services and system.

Community theater is a phenomenon that has been growing in Brazil and in the world, and has been described as 'a modality of theater that is difficult to define, since it takes various formats, related to different institutions and purposes" ${ }^{20}$. Pompeo Nogueira describes it as "a theater that is created collectively, which takes place through collaboration between artists and specific communities. The creative processes have their origin and their effect in the realities that are lived in a community, where such a community might be based on location, or interest ${ }^{20}$. As Kershaw puts it, according to Nogueira ${ }^{10}$ a practice can be categorized as Community Theatre, 'whenever the point of departure [of a theatrical practice] is the nature of its public and its community; whenever the aesthetics of its performances are sculpted by the culture of the community that is its audience? The principle is not that the theatrical activity should be thought of as 'a Band-Aid always ready to be applied to the wounds of the social fabric ${ }^{21}$, nor as something that is applied for the purpose of 'encouraging participants to adapt themselves more effectively to the world, but rather of encouraging them to imprint their own colors on the mast of social change' ${ }^{21}$. In this sense, 'art means communicating what life normally hides from us [...], expelling us from the zones of habit and of comfort, to change our notions of what we are and what we can be ${ }^{21}$.

Social support: Various authors refer to social support as being a dynamic and complex process and, as Martins ${ }^{22}$ points out, 'one that involves transactions between individuals and their social networks, in the sense of satisfying social needs, promoting and completing the personal resources that they have, to confront new needs and meet new objectives'.

According to Minkler, quoted by Valla ${ }^{23}$, social support is any information, spoken or otherwise, and/or material assistance offered by groups and/or persons, which produce systematic contacts that result in emotional effects and/or positive behaviors. This is a reciprocal process, that is to say, one that generates positive effects both for the subject who receives it, and also for the person who offers the support, enabling both to have more sense of control over their lives. 


\section{Methodology}

This is a qualitative ${ }^{25,26}$, ethnographic ${ }^{27}$ study, carried out at the Pombas Urbanas Institute / Art Under Construction Cultural Cente, or CCAC ${ }^{28}$, located in the district of Cidade Tiradentes, in São Paulo, and which in 2002 had the worst Youth Vulnerability Index in the whole of the municipality.

This initiative, which is an NGO, created and organized by the Pombas Urbanas theater group, was chosen after a survey by the investigators seeking an institution that offered theater lessons, with the following criteria: (i) in existence for more than three years; (ii) theater lessons being given to young people for more than one year; and (iii) located in the municipality of São Paulo in an area with low economic and social indicators. The NGO that was chosen offers free courses in theater, circus, capoeira, percussion, ballroom dancing, flamenco dancing and others, which vary with each six-month period, serving the public of children, young people and adults. It aims to offer the open possibility of a quality artistic training that includes human development.

The investigators were not previously aware of this NGO. The fieldwork was undertaken after authorization by the people responsible for is work at this location. All participants were informed of the presence of the researchers.

The location occupied by the group was a warehouse building which had been abandoned for 10 years and had become a location for use and dealing of drugs - a 'Drug Point'. With the intervention of the theater group since 2004, it has become a 'Culture Point' (Figures 1, 2, 3).

'Culture Points' are part of the Culture Ministry's Art, Culture and Citizenship - Culture Alive Program (Programa Arte, Cultura e CidadaniaCultura Viva ${ }^{29}$, which began to be implemented in 2004, and "aims to strengthen and empower cultural actions that have been undertaken by sectors that have been historically excluded from public policies" ${ }^{\prime 30}$. Existing groups are selected through public announcements/tenders and subsidized to enable them better to carry out

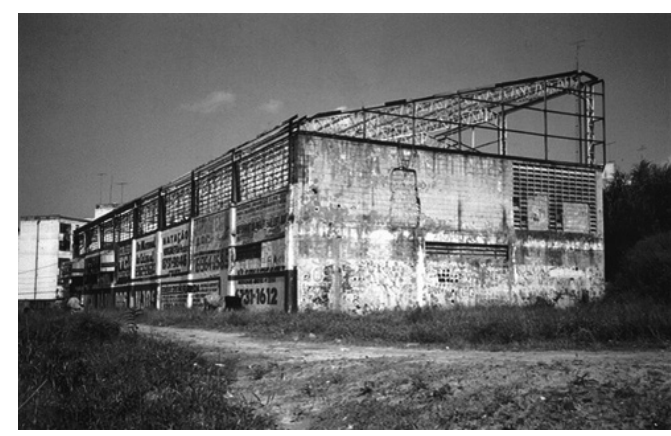

Figure 1: Abandoned warehouse; a 'Drug Point'.

Source: Files of Pombas Urbanas Institute.



Figure 2: Inviting young people to take over the process of transformations for themselves.

Source: Files of Pombas Urbanas Institute. 


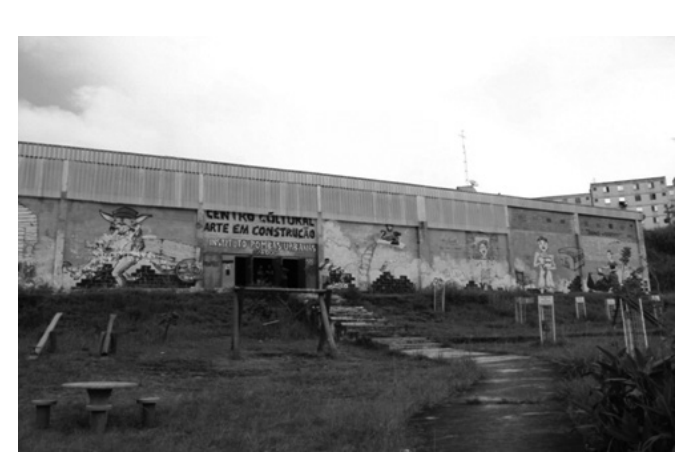

Figure 3: The location, transformed by/with/for young people: A Culture Point.

Source: Investigator's own files.

The collection of data took place through ethnographic observation in 60 visits over the year 2010, analysis of documents and 17 semi-structured interviews. Triangulation of data was employed to deepen understanding of the object of study ${ }^{25}$.

The visits took place on varied days, not always days that were predetermined by/for the subjects, making it possible to observe the young people within the CCAC and the relationships between them and between them and the community. Direct observations were recorded in a field diary.

The interviews, recorded with the consent of the interviewees and transcribed in full, were made individually, and in a private manner, after 29 visits to the location. They were carried out by one of the investigators with 12 young people between the ages of 15 and 29, who were practicing theater in the location for more than a year and comprised the groups that were formed or in the process of formation, and with five actors of the Pombas Urbanas group, between the ages of 32 and 40, and who had a life history very relevant to the study: They were young people from the poor city-fringe districts who began the theatrical experience in a workshop proposed by the government and, from it as a starting point, formed a theater group with a range of actions in/for/with the community.

Interviews were held with all the actors of the Núcleo Teatral Filhos da Dita group and four actors of the Pombas Urbanas Group, who had begun to practice theater with Lino Rojas, at ages between 13 and 19, and one who began at 27; two young people of the Youth Group, and one young person from the Beginners' Group, who had been practicing theater at the location for more than a year, totaling 17 interviews, of which 11 were male and six female.

The interviews had a broadly organized script structure, including both closed- and open-ended questions. The interviews were of varied duration, but mostly between two hours and two hours 30 minutes. Each one was made in a single 'shot', with one exception only, which was due to the interviewee having commitments. After the start of the interview, there was continued observation of teaching sessions, and other events, carried out with intense participation by the young people. The true names of the interviewees were replaced by names of flowers, to ensure anonymity.

For the analysis of the content, the interviews transcribed, the field diary, and material acquired in the field, such as, for example, the newspapers produced by the group, were read and re-read several times - so as to enable full 'absorption' of the content; and to assist in decisions about excerpting, and grouping into categories - and analyzed based on the theoretical reference points of the study for the purpose of an analysis by subject ${ }^{26}$.

Our analysis and discussion of the results that we found was based on the view of promotion of health as giving value to social determinants of health and of illness, and not only to individuals in isolation.

The study was submitted to the Ethics Committee for Analysis of Research Projects (CAPPesq) of the Clinical Directorate of the Hospital das Clínicas of São Paulo and of the Medical Faculty of São Paulo University, and approved. All interviewees signed the Informed Consent Form.

\section{Results and discussion}

This article supports and strengthens the concept that certain artistic and cultural experiences, carried out outside the health services, also contribute to the promotion of health.

Several authors recognize the importance that social support has for the promotion of the health of individuals $s^{6,23,24}$.

Our analysis seeks to describe how social support takes place through the theatrical experience that we studied, and in what way this experience can be considered as a factor promoting health or increasing the potential for health. 


\section{True friends}

Since the start of fieldwork it was perceived that the people involved considered that theatrical experience was making it possible for them to build significant links of affection because they made friends with whomever they felt the greatest affinity and intimacy with.

At the opening [of the Second Community Encounter of Young Theater of São Paulo City], a young man read a text that said that through theater, 'friendships result, friendships are caused and new friends become known'. (Field diary, November 15, 2009)

In the young people's perception, the establishment of these links of affection is important because they are deeper and consist of relationships with space for care and dialog:

... And after the lessons there was a space for conversation, we exchanged ideas. Then I began to make friends here who were very much stronger than the friends I already had. The friends that I had here listened to me. I listened to them, I learned from them, I really learned good things from them. (Flor, age 19)

...We are friends, too, so as to exchange, and also to demand things from each other. Because in the Group [the Filhos da Dita Theater Group] one thing that never happened was for us to avoid controversy. [...] And the other friends from outside, I don't have much contact with the friends from school, but I always saw that it was very different. (Daisy, age 19)

When asked about what was different in relation to friends from school, interviewees strengthened the hypothesis that theatrical activity can contribute to strengthening of a group, perceived by them as freer and more individualist:

... [At the school] it's not very close. You don't feel a liberty. [...] Because in the Group [Filhos da Dita Theater Group] or in the theater, you feel a liberty because you are making theater with the other person, you're exchanging with the other person, you believe in the same things. And in a school it's not like that. (Daisy, 19)
... [At the school] this thing of the collective, I feel that it's a lot less. It's each person thinking of themselves. That doesn't mean I can't talk to them, have relations with them, be friends, visit, go out together, but it's different. (Azalea, age 22)

The fact of it being essentially a group art has importance in this aspect that is highlighted:

...One thing that we say is 'you can't do theater alone.' I think that this contact with the other is the great element. Because it's not the superficial contact, it's the contact right there, you are feeling the other person, the breathing, you know - the heat, the sweat, everything. (Acacia, age 23)

As well as the theater being an art that tends to strengthen the links between the members of a group, in the case that was studied there was a collective life project - arising from this strengthening of both the individual and the group - of maintaining a cultural space (the CCAC) with courses, shows and other free activities carried out for the community.

All this experience, which included a range of things from theatrical exercises to the construction of collective projects, contributes to the development of mutual cooperation and integration. In the view of those interviewed, this makes possible an increase of confidence and the security of having someone to count on if necessary, which are characteristic elements of social support and are fundamental for the promotion of health ${ }^{12,13,15-17,24}$ :

...To know that you have a support. Sometimes, even when you do something wrong, and also when things are going right, you know that everybody is supporting each other. [...] Because we don't ... It's not like, each one has his function and does it for himself. If I'm only changing a plug, I know that it's for the good of everyone, you understand? (Lily, 25)

...And I think that this also results in our respecting each other, that we help each other. [...] So, we feel even like a safe haven. (Azalea, 22)

The solid experience of living together with the group made it possible for meetings to be motivated not only by the desire to do theater, but also by the friendship that surrounded them. Some, even, decided to live together and share expenses.

These links contributed to their organizing themselves to think of joint activities, such as preparing a meal, going to the cinema, theater, parties organized by this or other theater groups where the abuse of alcoholic drinks and/or drugs was not welcome. It is noted, as they themselves said several times, that the option not to abuse drugs arises from the fact of having a life project and not from imposed rules or campaigns. 
This artistic experience seems to give rise to the formation of young people who are critical of egocentricity, prejudice and competitiveness. They are attentive to the problems of their peers and of the community, and seek to be the protagonists in actions that aim for change:

...But I think that this path that the theater opens up is not only a path of professionalization, of being an actor. It's also a way toward you being more sensitive to things, being more concerned about the other person [...], not only thinking of yourself [...] if everybody went through some time in the theater at some moment in their lives, I think that people would be more comprehensive, more loving, more affectionate, more sensitive. (Azalea, 22)

...They are friends you can count on [...]. Sometimes, one has a problem at home, then the other person says 'ah, I've already been through that, I can help you in the following way'. I think that it's this that's so cool - that a person is not only a friend in the Cultural Center, he's also a friend when he's in the school, when he's in the street, he's always together, really. (Arum Lily, 17)

\section{Dialog: A necessity}

The existence of a space for being heard enables young people to feel more respected in their rights and duties, which is something that is pointed to as of fundamental importance in the document National Dialog for a Public Policy for Youth $^{33}$. We know that when these spaces are not found, there is a higher probability of suffering and illnesses, and a greater difficulty of dealing with them ${ }^{1,8,29,34-38}$.

This can be observed in these comments by the young people:

...Age 14, you begin to discover and see the world in another way, to seek your space in the world. And in this space I felt good. I felt that when I proposed some things I was heard, I knew how to listen to the other person as well. This energy of integrating people, [...] of my feeling integrated, a part of things, of being able to speak, was very important for me at that moment. (Daisy, 19)

...It instigates you to read, to observe more, to hear, to give more value to hearing than to speaking. I think that the theater changes a lot in this way, really a lot. (Stock, 16)

This is even more important if we consider that often the young person has not been finding this space for being listened to in his or her family or school:

...And here we opened a space with the theater, a space that is more for opening up, conversing, talking about the problems. But with my family I never had this much. Here I certainly have it. When I'm down, or when I'm happy, in my intimate self, I have a greater sense of security for sharing it. (Lily, 25)

... We can say things, put things forward, but we're not listened to about those things. And they always have an answer ready: 'You're a pupil, now you just study, your duty is to study and not to arrive late.' (Goldenrod, 17)

The importance of this 'hearing and being heard' and the idea that all were considered important for the functioning of the group and of the space and could contribute in many ways was emphasized from the moment of a young person's arrival:

P. said that he believed in the theater as a transformative agent and believed in taking a lead - taking up a stance and putting it forward. He also said that they believed in an open teacher/pupil relationship, not an authoritarian one, and that 'nobody is better than anyone else.' (Field Diary, March 13, 2010, first day of lessons of the Beginners' Group.)

This care for the other could be perceived in the various actions that the young people, as protagonists, were carrying out in the community. We also took support from the position of $\mathrm{Luz}^{6}$, affirming the importance of the renewal of sociability, making of new friendships and the possibility of social exchanges (information, experiences and orientations) in the promotion of health, since they "become small and multiple points of resistance to the dominant individualism, putting fraternity and cooperation in the place of the dominant value of competition".

It was interesting to observe that the young people did not passively expect only to be met in their demands, but there was a critical consciousness of rights and duties that had its repercussions in actions outside the CCAC:

...What we learn here we take out there, into the school, and into our home. We learn to live together, to be together. (Stock, 16)

When asked whether the experience with the theater had contributed to a desire to do voluntary work with young people in a Testing and Counselling Center (CTA), 'Stock' answers:

...Of course. It's the easiest way for you to communicate. When you know how to listen, you know how to communicate. [...] When we do theater, we have a way, a knack, of being able to talk with people. Ah, I think that we see everybody as equal, independent of sex, or option (Stock, 16)

Dialog was constantly given priority, both for going deeper into the understanding of cer- 
tain questions and also for the solution of daily personal collective problems. The importance given to dialog is fundamental in this relationship that we are establishing between this joint experience of theater, social support and promotion of health - as discussed by Paulo Freire ${ }^{36-38}$. According to Freire ${ }^{37},[. .$.$] it's not by talking to oth-$ ers, from the top downwards, as if we were the sole bearers of truth to be transmitted to others, that we learn to listen, but it's by listening that we learn to speak to them. Only someone who listens patiently and critically to the other person, properly talks with that person, even if, in certain situations he needs to talk 'to' that person.

Since the arrival of the Pombas Urbanas group in Cidade Tiradentes, young people have been invited to take part in a reflexive and active manner in the activities and the construction of the actions to be carried out there, developing a critical and active policy in relation to various daily individual, collective, institutional or community situations.

It was possible to observe that the young people helped the Pombas Urbanas group to maintain the other actions that were directed towards the community - which included free cultural activities at weekends, lessons in theater and circus for children, theater meetings, etc. Depending on their interests they were invited to improve their aptitudes and contribute to the permanent construction of the space. In the field diary there are records of activity by young people on various occasions, it always being highlighted that they did things with pleasure and maturity.

When the doors closed because the public was arriving, some were outside helping organize the people waiting in line (and telling them that the tickets had already been sold out), some were filming and photographing [...], and some were giving that last bit of support to the actors and production of the group. (Field diary, April 26, 2010, p. 404.)

In Paulo Freire's view, true dialog and transforming practice mean action and reflection that are radically integrated. This means that the actions cannot be restricted, neither to a 'whole bunch of words and blah, blah, blah'38 nor to 'unrestrained activism', and that 'any of these dichotomies, being generated from non-authentic ways of existing, generates non-authentic ways of thinking' $^{38}$.

Dialog goes a long way beyond a simple space for listening to impatient self-expression or needs, and 'cannot be reduced to an act of unloading one person's ideas onto another, nor can it become a simple exchange of ideas to be consumed by those exchanging ${ }^{38}$. Within this concept of dialog, we emphasize the horizontal nature of the relationships and the capacity for action. Mutual respect was observed when they attended parties, took part in meetings for organization of the space, or preparation and carrying out of new projects, or research for tenders for funding to improve the space, etc.

Each individual's knowledge was respected and given value in a range of ways, but we point here to some moments that showed clearly the importance given to this aspect by actors of the Pombas Urbanas group.

P. began by saying to the group that he was happy that T. and L. were doing good work, while they (of the Pombas group) were away for the weekends giving shows. [...] He also talked about the importance of transferring to other people (a piece of knowledge, a function, responsibility, action), and from that as a basis, to be able to build [...] new things. (Field diary, April 26, 2010, p. 388.)

According to Paulo Freire ${ }^{38}$, "how can I hold a dialog, if I feel myself to be a participant in a 'ghetto' of the pure, 'owners of the truth' and of knowledge, for whom all those that are outside are 'those people', or are 'inferior natives'?"

Attitudes of respect for the other were observed when these young people were, as multipliers, giving lessons or organizing various events. In an event for children and adolescents of the community, in which they experimented with circus numbers (which the Pombas Urbanas Institute carries out annually), there was an intense participation by the young people in all of the organization.

Just before opening the space, they checked to be sure that everything was all right, that each person was ready at the place required for their function and the space could be opened. All this was done by an adolescent, without anyone [...] coordinating: "now do this, do that". (Field diary, February 25, 2010, p. 95.)

Another significant situation is when the young people, in the absence of the actors of the Pombas Urbanas group, take care of the space, which includes giving the lessons to the beginners' group. In a period of one month, while some young people were travelling with the group to carry out their functions as illuminators, sound operators, etc., others made it possible for the CCAC to remain open and with all the activities taking place normally.

The lesson took place normally and the pupils respected the conduct of the lesson, even the girls being a little more tolerant of minor cases of late- 
ness and more permissive for some playing of jokes between the boys. (Field diary, April 10, 2010, p. 328).

In the initial warmup of one of these lessons,

This reinforces the importance of the participation of the young people in the preparation and discussion of the specific programs that they are part of, so that they will have greater adhesion, quality, efficacy and so that there is a 'real' and not 'symbolic' participation'.

A point that is emphasized by Resende Carvalho is the importance of 'community empowerment' in processes for the new vision of promotion of health, which has emerged to contest 'strategies directed to regulation and vigilance over social and individual bodies, with profound political, moral and social implications ${ }^{18}$.

Permeating these points, we re-emphasize that access to artistic knowledge, because it is 'something that provides space for acceptance of aspirations, desires, needs, abilities and interests' ${ }^{35}$, can become 'a place of multiple events of approximation of individuals, and also of collective participation ${ }^{35}$, where it is possible for 'individuals to connect with life, with the environment, with others, and with their own subjectivity ${ }^{35}$.

\section{Final considerations}

The practice of theater that was studied provides positive changes in social support, through a more solid network of friends, with capacity for dialog, care, reduction of individualism and increase of critical capacity.

Although CCAC is not a traditional health space and does not have promotion of health as a specific objective in its actions, we consider that the way in which it conducts the possibilities of the theatrical experience promotes health. The difference that we want to emphasize is that the theatrical experience, experienced jointly, is not a strategy for discussing questions of health in an imposing and rule-making way, nor is it a resource for directly achieving objectives related to the absence of illnesses.

What makes this experience a practice that promotes health is the fact that it makes it possible for the young person to have access to culture as a citizen with rights and duties and not, a prio$\mathrm{ri}$, as a vulnerable young person who is in need of assistentialist practices. It is also distinguished by the fact that it makes it possible for them to have a greater understanding of political-social ques- tions and, from this as a starting point, choice of a plan for life and conditions for achieving it. This movement of the point of focus (from the place in which the poor young person is necessarily of high risk to society, to the place of a young person with various capacities) is one of the characteristics that differentiates this experience. In this context, art is a promoter of health because it means "the recognition and communication of our 'power to' in contrast to the contemporary policy context that devotes its energies to 'power over ${ }^{21}$ ", a fundamental element of what we are considering to be social support.

All this takes place because, in the way it is developed, the experience that was studied stimulates young people to discover and develop their potentialities, giving value to the actions carried out for/with the community in which they live, and the spaces for exchange, dialog and a critical stance.

Our results re-confirm that interventions in favor of promoting health - as is recommended in the PNPS - can and should go far beyond both the health services, and any orientation for acquisition of healthy habits in an individualist and rule-making way. They also confirm the importance of the cultural sector in the promotion of health, as was already indicated in the documents of the health promotion conferences and in the Ottawa Letter ${ }^{15-17,19}$.

We intend, with these results, to support the idea that health is a product of a wide spectrum of factors related to quality of life ${ }^{12,15,16,19}$ and, thus, as Buss ${ }^{39}$, points out, calls for activities that are directed to the collectivity of individuals and to the environment (in a broad sense, of physical, social, political, economic and cultural environment), through public policies and conditions favorable to the development of health and of empowerment of the capacity of individuals and of communities.

For this, the promotion of health should take place in 'articulation and coordination between the individual and the collective, between public and private, between state and society, between the clinic and policies, between the health sector and other sectors - aiming to break down the excessive fragmentation in the approach to the process of health-illness and to reduce the vulnerability, risks and damages that are produced in it ${ }^{12}$.

Considering that the social and political engagement of young people in Brazil is still low, that the possibility of new forms of participation is emerging, that access to art and culture is a right, and that it helps in the promotion of 
young people's health, we argue for continuity of the public policies that support 'Culture Points".

Theater activity does not offer 'guides for change'21, but it 'places the human imagination and consciousness within a paradigm in which change is possible; a place where we, individually and collectively, accept responsibility for the world ${ }^{21}$. It is in these joint responsibilities, strengthened by this group art, that the intersection takes place with social support and promotion of health.

We conclude this article affirming that, if poverty of relationships is a factor that is dam- aging to health, a practice that favors the formation of social networks and of social support for young people and the integration of different generations can and must - integrated with other actions - be considered as very favorable to the promotion of health ${ }^{40,41}$.

It is proposed that promotion of health 'goes far beyond the pursuit of values that are moral abstract precepts, to a positive quest for liberty and happiness ${ }^{30}$; and that the new actions are not 'a simple professional task, but an effective meeting of human beings ${ }^{30}$. Community Theater can be a way forward.

\section{Collaborations}

D Diba and AF d'Oliveira participated equally in all stages of preparation of the article.

\section{References}

1. Barros DD, Lopes RE, Galheigo SM. Novos espaços, novos sujeitos: a terapia ocupacional no trabalho territorial e comunitário. In: Cavalcanti AA, Galvão CRC. Terapia Ocupacional: fundamentação e prática. Rio de Janeiro: Guanabara Koogan; 2007. p. 354-363.

2. Boghossian CO, Minayo MCS. Revisão sistemática sobre juventude e participação nos últimos 10 anos. Saúde Soc 2009; 18(3):411-423.

3. Castel R. As metamorfoses da questão social: uma crônica do salário. Petrópolis: Vozes; 2005.

4. Castro MG, Abramovay M, Rua MG, Andrade ER. Cultivando vida, desarmando violências: experiências em educação, cultura, lazer, esporte e cidadania com jovens em situação de pobreza. Brasília: Unesco, Brasil Telecom, Fundação Kellogg, Banco Interamericano de Desenvolvimento; 2001.

5. Centro de Estudos e Pesquisa em Educação, Cultura e Ação Comunitária (CENPEC). Juventudes: panoramas e iniciativas com foco na juventude de São Paulo. São Paulo: Peirópolis; 2007.

6. Luz MT. Novos Saberes e Práticas em Saúde Coletiva: Estudos Sobre Racionalidades Médicas e Atividades Corporais. São Paulo: Hucitec; 2007.

7. Novaes R, Vannuchi P, organizadores. Juventude e Sociedade. Trabalho, Educação, Cultura e Participação. São Paulo: Instituto de Cidadania, Fundação Perseu Abramo; 2004.

8. Simson ORM, Park MB, Fernandes RS, organizadoras. Educação não-formal: cenários da criação. Campinas: Editora da Unicamp, Centro de Memória; 2001. 
9. Diba D. De ponto de drogas à Ponto de Cultura: juventude, teatro e promoção da saúde - o grupo Pombas Urbanas em Cidade Tiradentes [dissertação]. São Paulo: Universidade de São Paulo; 2012.

10. Nogueira MP. Teatro e comunidade. In: Florentino A, Telles N, organizadores. Cartografias do ensino do teatro. Uberlândia: EDUFU; 2009. p. 173-183.

11. Nogueira MP. Teatro em comunidades: questões de terminologia. In: Anais do V Congresso da ABRACE; 2008; Belo Horizonte. [acessado 2011 mar 06]. Disponível em:http://www.portal abrace.org/vcongresso.

12. Buss PM, Pellegrini A. A saúde e seus determinantes sociais. Physis 2007; 17(1):77-93.

13. Vaistman J, Andrade GRB. Apoio social e redes. Cien Saude Colet 2002; 7(4):925-934

14. Valla VV. Educação popular, saúde comunitária e apoio social numa conjuntura de globalização. Cad Saude Publica 1999; 15(2):7-14.

15. Brasil. Ministério da Saúde (MS). Política Nacional de Promoção da Saúde. Brasília: MS; 2010.

16. Brasil. Ministério da Saúde (MS). As Cartas da Promoção da Saúde. Brasília: MS; 2002. [acessado 2011 jun 20]. Disponível em: www.saude.gov.br/bvs/conf_tratados .html

17. Buss PM. Uma introdução ao conceito de Promoção da Saúde. In: Czeresnia D, Freitas CM, organizadores. Promoção da Saúde: conceitos, reflexões, tendências. $2^{\mathrm{a}}$ ed. Rio de Janeiro: Fiocruz; 2004. p. 15-38.

18. Carvalho SR. As contradições da promoção da saúde à saúde em relação à produção de sujeitos e a mudança social. Cien Saude Colet 2004; 9(3):669-678.

19. Czeresnia D, Freitas CM, organizadores. Promoção da Saúde: conceitos, reflexões, tendências. $2^{\mathrm{a}}$ ed. Rio de Janeiro: Editora Fiocruz; 2004.

20. Nogueira MP. Tentando definir o Teatro na Comunidade. In: Anais da IV Reunião Científica de Pesquisa e Pós-Graduação em Artes Cênicas; 2007. Belo Horizonte. [acessado 2011 abr 20]. Disponível em: http://www. portalabrace.org

21. Prentki T. Contranarrativa - Ser ou não ser: esta não é a questão. In: Anais do I Seminário Teatro e Comunidade; 2009. Florianópolis. p.13-36.

22. Martins RML. A relevância do apoio social na velhice. Revista Millenium [ISPV] 2005; (31):128-134.

23. Valla VV. Apoio Social e Saúde:buscando compreender a fala das classes populares. In: Costa MV, organizador. Educação Popular Hoje. São Paulo: Loyola; 1998. p. 151180.

24. Canesqui AM, Barsaglini RA. Apoio social e saúde: pontos de vista das ciências sociais e humanas. Cien Saude Colet 2012; 17(5):1103-1114.

25. Flick U. Introdução à pesquisa qualitativa. Porto Alegre: Artmed; 2009.

26. Minayo MCS. O desafio do conhecimento: pesquisa qualitativa em saúde. São Paulo: Hucitec; 2008.
27. Geertz C. A interpretação das culturas. Rio de Janeiro: Zahar; 1979.

28. Silvestre N. Esumbaú, Pombas Urbanas! 20 anos de uma prática de Teatro e Vida. São Paulo: Instituto Pombas Urbanas; 2009.

29. Instituto de Pesquisa Econômica Aplicada (IPEA). Cultura Viva: as práticas de pontos e pontões. Brasília: IPEA; 2011.

30. Pereira CM. Política pública cultural e desenvolvimento local: análise do ponto de cultura Estrela de Ouro de Aliança, em Pernambuco. In: Barbosa F, Calabre L, organizadores. Pontos de cultura: olhares sobre o Programa Cultura Viva. Brasília: IPEA; 2011. p. 195-227.

31. Turino C. Ponto de Cultura: o Brasil de baixo para cima. São Paulo: Anita Garibaldi; 2009.

32. Lopes J. A ação griô: uma proposta política nacional. In: Barbosa F, Calabre L, organizadores. Pontos de Cultura: olhares sobre o Programa Cultura Viva. Brasília: IPEA; 2011. p. 139-154.

33. Ribeiro E, Lânes P, organizadores. Diálogo nacional para uma política pública de juventude. Rio de Janeiro, São Paulo: Ibase, Pólis; 2006.

34. Ayres JRCM. Cuidado: trabalho e interação nas práticas de saúde. Rio de Janeiro: CEPESC, IMS, UERJ, Abrasco; 2009.

35. Castro ED, Silva DM. Atos e fatos de cultura: territórios das práticas, interdisciplinaridade e as ações na interface da arte e promoção da saúde. Rev Terapia Ocupacional USP 2007; 18(3):102-112.

36. Freire P. Educação como prática da liberdade. Rio de Janeiro: Paz e Terra; 1975.

37. Freire P. Pedagogia da autonomia: saberes necessários à prática educativa. São Paulo: Paz e Terra; 1996.

38. Freire P. Pedagogia do oprimido. Rio de Janeiro: Paz e Terra; 1978.

39. Buss PM. Promoção da Saúde e qualidade de vida. Cien Saude Colet 2000; 5(1):163-177.

40. Ayres JRCM. O jovem que buscamos e o encontro que queremos ser: a vulnerabilidade como eixo de avaliação de ações preventivas do abuso de drogas, DST e AIDS entre crianças e adolescentes. In: Tozzi DA, Santos NL, Amaro CM, organizadores. Papel da educação na ação preventiva ao abuso de drogas e às DST/AIDS. São Paulo: Fundação para o Desenvolvimento da Educação; 1996. p. 15-24.

41. Ayres JRCM. Sujeito, intersubjetividade e práticas de saúde. Cien Saude Colet 2001; 6(1):63-72.

Article submitted 11/08/2014

Approved 15/10/2014

Final version submitted 17/10/2014 